\title{
Editorial
}

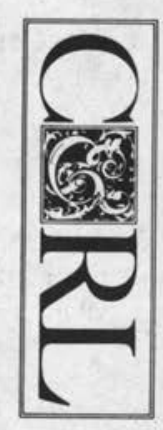

\section{Let Us Put Up Our Bright Swords}

Is there a crisis in higher education? Many say yes. At MIT a sweeping reform of undergraduate education is under way. "We're not considering just a fine tuning of the curriculum, but a recasting of the educational mission" says President Paul E. Gray (Chronicle of Higher Education, Oct. 22, 1986, p.1). This approach is advocated by Ernest L. Boyer, the former U.S. Commissioner of Education, who believes "any college that has not thought carefully about goals should not even open the issue of college-wide assessment" (Chronicle of Higher Education, Oct. 15, 1986, p.41).

The dialogue in higher education over goals, curriculum, and the assessment of learning is both fascinating and instructive. Librarians who follow it are likely to observe interesting parallels with key issues in their own profession. In the literature of librarianship there is frequent mention of the need for strategic planning, the transformation of roles and programs, and the desire for the assessment of outcomes.

Meanwhile, October was a lively month for higher education. Just a few miles down the Charles River from MIT, another president, Derek Bok, was busy defending his university's curriculum in a dialogue with William J. Bennett. The secretary of education, helping Harvard celebrate its 350th anniversary, critiqued the university's curriculum reform efforts and chastised the spokesmen of higher education for invoking "the mission of the university as if they were reciting the Nicene Creed: one, holy, universal, and apostolic church" (Chronicle of Higher Education, Oct. 15, 1986, p.27).

Bok challenged Bennett to "live by the intellectual standards of the academy: meticulousness in the respect for available evidence, care in stating conclusions, perceptiveness in exploring issues beyond the level of superficiality and cant" (Chronicle of Higher Education, Oct. 22, 1986, p.17).

Bok has a point. Unfortunately, he is not upbraiding an academic colleague but a public official. The standards for discourse are not the same. And he knows this. Bennett knows this. We know this. The dialogue, handled with such finesse by Bok, who was not scheduled to speak before he received an advanced copy of the secretary's remarks, was a slugfest over turf.

Attack and counterattack will not solve the crisis. The posturings to protect intrinsic interests, or turf, will not allow us to agree on what is wrong and what needs to be done.

In his concluding statements, Bok balances the record when he notes that the real issues are not simply "what our students should learn but how well they are learning and whether they could learn better." He suggests six specific illustrative questions:

- How well do we formulate the purposes of our educational programs and communicate them to our students?

- How carefully do we adapt our individual courses and examinations to serve our shared educational goals?

- How can we improve the quality of feedback we offer our students without overwhelming a faculty already busy with many important goals?

- How can we identify early those who are achieving below their potential and how can we 
diagnose the source of their difficulties and help them overcome it?

- How can we exploit the possibilities and avoid the pitfalls of new technology to enhance the quality of learning?

- How can we evaluate the effectiveness of our educational programs and teaching methods, recognizing that no human endeavor can progress very far without some means of assessing its results?

The answers to these questions are critical. However, neither public officials nor academic administrators are the most relevant parties in the area of educational reform. The key participants can be found in only one place: the classroom. Yet, according to two professors, little attention has been paid to the role of teacher, the act of teaching, or ineffective teaching [Toby J. Tetenbaum and Thomas A. Mulkeen, "Designer Teacher Education for the Twenty-First Century," Journal of Higher Education (Nov./Dec. 1986)].

Because faculty rule the classroom and are protected by academic freedom and tenure rights, meaningful reform will proceed slowly, if at all, unless there is widespread faculty support. Without this support reform is doomed, no matter what the objective merits of the case.

The self-interests of the faculty cannot be ignored. Yet what incentives or reasons can others provide that might lead faculty to set aside these interests and accept assessments as a means for determining results and making improvements?

Assessment is a difficult issue. In view of the large sums of money spent on books and other media by library selectors, it would seem reasonable to expect that they would conduct systematic and periodic collection assessments as part of their basic fiduciary responsibilities. However, no such professional norm exists. Likewise, the assessment of performance at the reference desk has been the subject of theoretical interest, but there is no professional norm in place that leads us to do this.

In concluding his remarks, President Bok urged Secretary of Education Bennett to "put up our bright swords" in order to work together to solve common problems. We also need to build the cooperative relationships that will permit us to lower the shields of professional self-interest.

\section{CHARLES MARTELL}

\section{IN FORTHCOMING ISSUES OF COLLEGE \& RESEARCH LIBRARIES}

Faculty Status for Academic Librarians: A Review of the Literature

by Emily Werrell and Laura Sullivan

Managing Change: Supporting Users of Integrated Library Systems

by Gary Marchionini and Danuta Nitecki

The Nature of Authority and Employee Participation in the Management

of Academic Libraries

by Charles Martell

Modeling the Selection Decision: Defining Criteria, Making Microdecisions,

Establishing Priorities

by John Rutledge and Luke Swindler

Preservation Study at the Syracuse University Libraries

by Randall Bond, Mary DeCarlo, Elizabeth Henes, and Eileen Snyder 